\title{
The non-polis and the game of mirrors: Rome and Carthage in ancient and modern comparison ${ }^{1}$
}

\author{
Nicholas Purcell \\ University of Oxford \\ 'It is not for the purpose of extolling the Romans or the Carthaginians that I have offered these \\ remarks - I have often had occasion to bestow praise on both peoples’ (Polybius 9.9.9).
}

\section{Dorsum immane mari summo (Aen. 1.109): identifying Altars}

In 2000, and again in 2002, the international press speculated about the possible re-emergence of one of the thaumata of Mediterranean geography, the famous ephemeral island of the Graham

\footnotetext{
${ }^{1}$ I am grateful to Denis Feeney for his invitation to an imaginatively-conceived and productive discussion, and to Princeton for its excellent hospitality. My ideas have also been enriched by many conversations with Jo Quinn. A version of this paper was also presented at the Maison Française d'Oxford, and I thnk Catherine Darbo-Peschanski for that occasion and further useful ideas.
} 
Bank, off the south coast of Sicily. In fact, its only modern appearances remain three in the nineteenth century, in 1831, 1846, and 1863. On its first discovery, Britain, France and the Kingdom of the Two Sicilies scrambled to claim a previously unknown piece of territory $4 \mathrm{~km}$ round, and 60 metres high, to be called Graham Island, île Julia, or Isola Ferdinandea, according to your allegiance. Despite the international interest, on each of these occasions, Ferdinandea soon vanished. Being composed entirely of loose volcanic scoriae, eruptive cones extruded from time to time, like this one, from submerged volcanic massifs, are very vulnerable to tide and storm, and intrinsically short-lived. Ferdinandea's staccato recent history, however, offers something of real interest to the historian of the long encounter of the Carthaginian and Roman polities, which is why it forms the starting point of this paper.

Here, or hereabouts, a mysterious ancient landmark was situated - the Propitious Altars, the Altars of Neptune, the site of observances by Carthaginian priests, the conceptual boundarypoint at which a treaty between Rome and Carthage, defining their respective imperial domains, was struck. Neglected undeservedly, the evidence on which I base this claim also illuminates the mutual estimations of Carthaginians and Romans, and how those symmetrical, cris-crossing evaluations served to shape a pair of twin polities, made to converge by mutual perception.

The evidence for the treaty of the Neptunian Altars, which locates them in all probability on the Graham Bank, depends on Virgil's elaboration of the storm which drove Aeneas' fleet every which way across the Ionian Sea at the opening of the narrative of the Aeneid: 'three snatched away the South wind twirls aside onto hidden rocks - rocks out in the middle of the ocean which the Italians call the Altars, an enormous massif under the open sea' (Virgil, Aen. 
1.107-9). ${ }^{2}$ Another three ships are blown to the Syrtes. It has been seen that these dangerous waters represent the eastward boundary of future Carthaginian power. The three ships driven to the north, however, foreshadow a more ominous confrontation, that of Dido's descendants and the 'Itali' who here so specifically (and unexpectedly) name the Altars where these Trojans suffer. Virgil does not specify the location and point to its familiarity to mariners from Italy by accident. Given the associations of the Syrtes with the eastern boundary of Carthaginian power marked by the Altars of the Philaeni, his purpose is very likely broadly to have been that already identified by the scholiasts. ${ }^{3}$ This was, they saw, where Aeneas’ descendants will one day make a fragile peace with Carthage on an almost invisible frontier, a stage in the saecular confrontation which will result from the Trojan arrival in Africa. It is these commentaries on Virgil which make possible the location of the symbolically resonant 'Altars' on the Graham Bank, and which prompt the observations of this paper about the comparison and comparability of Roman and Carthaginian polities. ${ }^{4}$

2 tres Notus abreptas in saxa latentia torquet (saxa vocant Itali mediis quae in fluctibus Aras dorsum immane mari summo)...

${ }^{3}$ Quinn 2011 and 2014.

${ }^{4}$ Servius, ad loc. [saxa latentia] haec autem saxa inter Africam, Siciliam et Sardiniam et Italiam sunt, quae saxa ob hoc Itali aras vocant, quod ibi Afri et Romani foedus inierunt et fines imperii sui illic esse voluerunt. unde et Dido “litora litoribus contraria, fluctibus undas inprecor”. quae 
Servius informs us of the names or epithets applied to the islands by the first-century BC historians Claudius Quadrigarius (Neptuniae) and Cornelius Sisenna (propitiae). ${ }^{5}$ The fuller version of the scholia (which is thought to contain more information from the commentary of Servius’ predecessor Donatus) specifies that it was in his first book of Annals that Quadrigarius used the phrase 'at the Altars which were called Neptunian'. Unspecified Greek authors called them bomoi. Varro, in his treatise de ora maritima, described how sailors on the route Sardinia to Sicily dread losing sight of those islands, because they might unexpectedly find themselves on the shoals of the place called 'Arae'. Unattributed information includes the treaty and the boundary-function, and the location 'between Africa, Sicily, Sardinia, and Italy' (the abbreviated version omits Italy and Africa). 'Some record' that the altars are the remains of an island which suddenly disappeared, where Carthaginian priests had been used to perform their rites. How

arae a Sisenna "propitiae" vocantur. alii dicunt Graecos haec saxa bomous appellare. quidam insulam fuisse hunc locum tradunt, quae subito pessum ierit, cuius reliquias saxa haec exstare, in quibus aiunt Poenorum sacerdotes rem divinam facere solitos. has aras alii Neptunias vocant, sicut Claudius Quadrigarius I annalium “apud aras, quae vocabantur Neptuniae”. Varro de ora maritima lib. I "ut faciunt hi, qui ab Sardinia Siciliam aut contra petunt. nam si utramque ex conspectu amiserunt, sciunt periculose se navigare ac verentur in pelago latentem insulam, quem locum vocant aras".

${ }^{5}$ Quadrigarius 24 F 34 Cornell, from Servius ad Aen 1.108-9; Sisenna 26 F 140 Cornell. 
much do these notices converge? Varro's Seashore, which seems to have been a Periplous, probably concerned mainly the navigational point which is preserved, but may have already attributed the name Arae to 'Italians' ${ }^{6}$ Sisenna's context for the allusion is unknown. ${ }^{7}$ All the other material might be fitted together, and attributed to Quadrigarius. The earlier author, whoever it was, also knew Greek texts which described a place which used to be called Arae Neptuniae - his tense implies that it was so no longer, so he knew that the island had disappeared and probably said so. On this view, the original Greek author or authors reported the veneration of the place by Carthaginians, and its selection as the site of a treaty between Carthaginians and Romans; and probably attributed to that treaty, the choice of the Arae as the indicator of the boundary between Carthaginian and Roman zones of maritime hegemony.

Here we have a notice of an important inter-community negotiation, presented with

${ }^{6}$ Compare Servius' other quotations from the work, such as ad Aen. 8.710 on an Apulian wind. Pliny HN 5.42 also knows (at least) two authorities: Arae autem scopuli verius quam insulae, inter Sardiniam maxime et Siciliam. Auctores sunt et has quondam habitatas subsedisse. This sounds very like Varro and Quadrigarius.

${ }^{7}$ For Briscoe 2013b, 416 Sisenna in his introductory material was making the same point as Virgil about Aeneas' journey. Given the complexity of purpose which even Servius sees in Virgil's geography of this storm, and the way in which it foreshadows the presentation of Romano-Carthaginian hostilities in the epic, that is unlikely. The other view, that Marius' crossing to Africa occasioned this allusion, fits Sisenna’s main subject-matter, remains possible. 
attention to religious observance, and so potentially rich in implications for the thought-worlds of those who carried out the transactions. It sounds important - why is it not more famous? Some scholars have been entirely skeptical: 'It is of course highly unlikely that Roman and Carthaginian envoys concluded a treaty on some inhospitable rocks in the middle of the sea. Nor could such rocks alone constitute a naval boundary' ${ }^{8}$ Such unlikeliness should at least generate some curiosity as to the purposes of the unconvincing inventors of such nonsense! But the apparently least likely detail of all, the sudden disappearance of the island, in fact offers a more positive interpretation, given the nature of the Graham Bank and its submarine volcano. ${ }^{9}$ The modern history of the islands there in the nineteenth century suggests that the venue for the treaty-making may have disappeared not long after the diplomatic event for which it was - dimly - remembered.

What can we say, then, of the date of the events, of this quite constructive, relatively balanced, negotiation between Romans and Carthaginians, and of Quadrigarius' possible sources? Above all, why, when we have such a splendid account in Polybius of precisely the long sequence of diplomatic relations between Carthage and Rome from 508/7 BC, does he not mention these matters? ${ }^{10}$ The simplest answer is that the treaty discussed (on this view) by

\footnotetext{
${ }^{8}$ Briscoe 2013b on Sisenna F 34.
}

${ }^{9}$ Vollmer 1877 already drew a rather general parallel with Ferdinandea.

10 Polybius 3.21.8-27.10, with an enormous bibliography, of which Scardigli 1991 is outstandingly useful. 
Quadrigarius is the one attested by Livy in $306 \mathrm{BC}$, which we usually call the 'Treaty of Philinus', and which was omitted by Polybius on the grounds that he explicitly didn't believe in its existence, but really because such a settlement rendered Roman intervention in Sicily at the beginning of the First Punic War legally contestable. ${ }^{11}$

My aim is to show how these events, and the Carthaginian-Roman mutual views and relations which they imply, and their religious overtones, are compatible with the end of the fourth century. That this place served as a notional delimitation of Carthaginian and Roman domains matters for the history of conceptual space, and for how imagined spaces bore on maritime hegemony. Here, moreover, is a testimony to an early stage in the formulation of Carthage and Rome as rival hegemonies. It also attests the geographical and cosmological construction of that antinomy, that binary comparability. And it reveals a stage in the distinction of such comparable imperial systems from the universe of poleis. All those implications may also help in discerning a possible author from whom the Roman annalists might have drawn their information.

11 Livy 9.43.26. Philinus of Acragas: Polybius 3.26.1-7, cf., for his Carthaginian partisanship,1.14.3 (FGH 174 F 2). Oakley 1998, 252-62, esp. 258-62; Scardigli 1991, 129-62; Heurgon 1969, 337; Walbank 1945; Cary 1919. Polybius 3.26.3-4 for the legality of Roman action. 
2. Litora litoribus contraria (Virgil, Aen. 4.628)

Comparing Carthage and Rome, studying them in parallel, is a project which needs some reflection. Antagonistic pairs formed a natural subject for ancient narrative, the comparison of foes being proposed already by the Iliad, and has a long historiographical legacy. But Carthage and Rome are not only deadly enemies to be analysed in that manner. Alongside the rather simplistic question of which of these two states influenced the other, which 'got there first' in different respects, the surprisingly large and complex dossier of similarities, crossovers, and borrowings between the two western hegemonies have suggested other approaches. ${ }^{12}$ This paper is written in an attempt to deploy one of them, the historiographical technique of histoire croisée, the study of regards croisés.

The aim is to sketch in brief an agenda for the joint study of Carthage and Rome based precisely on 'what they could have thought of each other', looking at mutual perceptions and how they crossed with and complicated each other. What I think of how you think of me changes how I think of you - and so on. Self-awareness and self-definition are seen out of the corner of the eye, shaped by a differentiation which is not primarily self-regarding. In this article I shall have space simply to outline three of these mirrored scrutinies, connected with the maritime, religion, and economic life. The exercise could be conducted in much greater depth and on a much larger scale.

The Virgilian phrase which forms the epigraph of this second section nicely conveys a

\footnotetext{
${ }^{12}$ Kolendo 1971; Marcotte 1988; Palmer 1997; Camous 2007.
} 
stand-off which to us seems intrinsically geographical:

'Our arms, our seas, our shores, oppos'd to theirs;

And the same hate descend on all our heirs!',

Dryden translated it. We think of the Peutinger Table depiction of the river-like Mediterranean, with Rome and Carthage facing each other on opposite banks rather than separated by hundreds of kilometres of sea. The simplification is natural. The nature of the border where two things meet is essential for understanding their character and how it was shaped by the sharing of that demarcation: but where was the interface between Carthage and Rome? For the late antique scholiasts, notably, Virgil's words had a different resonance: the legal language of treaties. Here, as in the scattering of the ships in Book I, they were reminded of the inter-community negotiations which we usually call 'diplomacy'. ${ }^{13}$ The utterances of treatynegotiation could serve to represent the participating peoples vividly. Polybius' set is so familiar to historians that we can fail to observe how interesting it is that he chose to use the medium of extensive quotation from just this kind of text as one of his equivalents for Thucydides' speeches of Archidamos and Pericles, the mise-en-scène of the great protagonists whose duel will pattern the history.

Polybius was not the first author to use treaties in his representation of this pair of polities. Discussion of the comparison of Carthage and Italy was found already in the peripatetic tradition. Aristotle spoke of the Etruscans and the Carthaginians (and other maritime peoples) as

${ }^{13}$ Servius, ad. Aen. 4.628. Indeed, the mention by the scholiast here of the status of Corsica is likely to be another allusion to the treaty solemnized at the Arae Neptuniae. 
being distinctive in the way in which they are constituted by sumbolaia, agreements about the practice of economic exchange (Aristotle, Politics 3.5.10-11). Polybius' use of treaties of just this kind is as eloquent an exposition of the Aristotelian theme as one could well wish for. Aristotle already has a two-fold vision of the West, an Italic part and a Carthaginian part, and this remained a theme in Greek interpretation: Eratosthenes spoke of the remarkable systems of governance of Romans and Carthaginians in parallel (Strabo, 1.4.9). But the idea of an extended comparison between Carthage and Rome had been developed - to what extent we cannot know by an author of whom Polybius did not at all approve - Timaeus of Tauromenium (Polybius 12.315). Discussion of the perceived comparability of these two systems, Carthaginian and Roman, must inevitably begin with Timaeus' unexpected proclamation (F 60 Jacoby) of the mirrored symmetry, shore to shore, city to city, continent to continent, empire to empire, destiny to destiny, of Carthage and Rome, by the synchronism of their foundations in the late ninth century. ${ }^{14}$ And, as I shall argue, it is to Timaeus' vision that we might ultimately want to retroject the first historical record of the treaty recorded by Quadrigarius.

Timaeus' analysis operated at a high philosophical level, characteristic of ancient historiography. The comparisons and contrasts of treaty-negotiations, however, shaped the views of a far wider range of people, from inter-community negotiators, through specialists in economic exchange, to those who reflected on which gods they worshipped and why, and the

\footnotetext{
${ }^{14}$ Thus already the acute remarks of Feeney 2007, 52-7 (cf. 92-100 for the significance of a historical date). Timaeus fr. $60=$ Dionysius 1.74 .1 for $814 / 3$ and the Rome/Carthage synchronism, with Asheri 1991-2 and Vattuone 1991.
} 
soldiers who constructed the character of their enemies. ${ }^{15}$ We need to include real crossovers of perception as much as the elegant patterns of theory, and that returns the argument to the soil-less wind-swept clinker of the Graham Bank.

\section{Fines imperii sui illic esse voluerunt: maritime and other hard-to-imagine spatialities}

It was said of the Arae that Carthaginians and Romans 'wanted the boundaries of their hegemonies to be situated there'. Wherever it originates, that is not an anodyne or commonplace claim. Edges are essential to the construction of the two things which they separate, and they affect that construction in parallel, being the mirror surface at which reflection and reality abut. The nature of the two systems in question is importantly reflected in their convergence at the Arae. As Rome and Carthage became mutually self-shaping twins, conceptual boundaries and contact-points between the systems took on an ever greater significance: we have only to look at how the Ebro or the Alps came to loom large in the thought-world of the later third century BC. But these are local demarcations: it was (and remains) hard to find a single symbolic edge between the domains. The treaties quoted by Polybius show us the delineation of Carthaginian and Roman interests from the sixth century $\mathrm{BC}$, and from the first it is one in which the impossibility of drawing a line on the map, the necessity of a differently conceived bounding, are

\footnotetext{
${ }^{15}$ Note also that Carthaginian and Roman negotiators were familiar with the whole sequence of agreements, reaching back across more than two centuries, Polybius 3.25.2.
} 
very evident.

Hegemonies whose boundaries were invisible found the perfect intermediary point in a sacred and ephemeral rock in the wide-open seas. That the Arae were a wonder, hard to classify, and evanescent, gave them a special suitability in the tricky and intangible business of defining sea-spaces. ${ }^{16}$ Quadrigarius’ anecdote displays a moment when Rome and Carthage were able and willing to conceive of themselves as hegemonies with a frontier between them, but based on their practical experience of navigation and the sea-spaces which made sense of it. This sensibility to maritime dominion drew on the geography of wonders of nature: Romans and Carthaginians could be partners in the religious construction which they put on the significance of localities of this kind, as in other aspects of the life of the sea.

Here an edge was proclaimed which was unlike the boundary between city-chorai, and unlike the limits of the same powers' terrestrial domains. This was a line in the sea, a line of the imagination, separating two entities which were maritime, and therefore constructed out of what was done at sea and by means of the sea, and out of how it was done, by the subjects of the imperial powers. ${ }^{17}$ Concepts of maritime space are formed by the practice and imaginations of

16 Wandering islands are a parallel: Moret 1997. Delos is perhaps most celebrated liminal wonder-island, the transition point between Persian and Greek waters at Herodotus 6.98, shaken by earthquake only when Datis’ invading force transgresses the limit.

17 Maritime anthropology helps see how complex such imaginations are, and how culturally specific: see for instance Langewiesche 2004 and Sharp 2005. 
those who use the sea as much as by geographical theorists reflecting on the dispositions of the surface of the globe. It required a sophisticated abstract imagination of the nature of political cohesion, starting with a conception of the spatiality of power on a more-than-chora scale. That concept had to be supple enough to be extended across maritime spaces which were not accessible to any easy or exact form of calibration. But it also entailed the weaving of a sense of control and integration out of many different kinds of activity, religious, military, demographic, and economic. The particular significance of the treaty of the Arae is that it displays the coevolution of Roman and Carthaginian maritime conceptual spaces.

The first treaty between Rome and Carthage suggests that classifying access to coastlines and seaways in quite sophisticated ways was already normal in the western Mediterranean in the late sixth century BC. ${ }^{18}$ Here too we find signs of the practical articulations of the abstract ideas, the actions whose patterns, resemblances, and regulation instantiated the ideas of otherwise shapeless maritime spaces on an un-intuitable geographical scale. Otherwise, early Roman ideas of maritime space have to be read back from scattered notices of the fourth century, the expedition to Corsica and the colonia on Ponza; from the incidence of Tyrrhenian 'piracy' in east as well as in west Mediterranean; from the place of socii navales in the Roman alliance system. ${ }^{19}$ Meanwhile, Carthaginian secrecy and exclusiveness in regard to the spatialities of the sea is on

\footnotetext{
${ }^{18}$ Polybius 3.22.5-6, exclusion-zones; 8-10 regions distinguished by the regulation of sale; 11-12 recognition of the differing allegiances of subjects and allies.

${ }^{19}$ For Roman seapower, see now the revisionist Ladewig 2014, with earlier bibliography.
} 
view in two passages of Strabo. The first is the dramatic account (3.11) of the attempts of Phoenicians of Gades to keep secret knowledge of the route to the Cassiterides, supported by a state (either Gades or Carthage, but probably the former). The second, more detailed account, concerns the history of Massalia. ${ }^{20}$ In his excursus on Massalia, Strabo speaks of the trophies there which derive from from the Massaliotes' long history of defeating in naval warfare (katanaumachein) those who 'unjustly made the sea debatable' (tous amphisbetountes tes thalattes adikos). The interesting, but oracular, phrase must allude to laying claim to exclusive rights to maritime activities, where Greek cities usually sought no control (though there are some exceptions). ${ }^{21}$

The difference between maritime and terrestrial conceptions of space is also helpful in addressing a problem which has inhibited general acceptance that the Arae should be sought on the Graham Bank - Varro's insistence on the place as a hazard on the Sicily-Sardinia route. ${ }^{22}$ Sardinia is in the picture as a direction and a horizon, so that the other description of the Arae, puzzling at first sight, as being between 'Africa, Sicily, Sardinia, and Italy', is the more helpful

${ }^{20}$ Massalia was also a subject for Timaeus, who discussed and dated the foundation (600 BC), in [Skymnos] 210-15.

${ }^{21}$ Strabo 4.1.5. Note for instance Thucydides 6.13 on the current limits of the Syracusans, the Ionian kolpos for the voyage para gen, and the Sicilian for the voyage dia pelagous.

${ }^{22}$ Varro may also have confused another dangerous (but non-volcanic) shoal such as the Skerki Bank with the now vanished island. 
one. We are dealing with the ideas of navigators and their senses of destinations and origins, and not with the representational logic of modern charts, with their capacity for an overview, a satellite-image, of the actual layout of the seas and lands. ${ }^{23}$ Here was a suitable place for those who actually sailed the narrow seas of the central Mediterranean to choose to mark a half-way stage, a central point, a significant reference, between these four apparently hard-to-relate navigational options. The logic of 'not sailing past such-and-such a coastal landmark' is extended to make sense of larger spaces crossed by routes which cannot be limited to coastal waters.

An example of such a coastal marker is a small hill on the eastern coast of the Egyptian delta where Herodotus (3.5) set the boundary of Egypt. Improbably enough, this place took its name from Mount Kasios, the great sacred landmark of the lower Orontes and north Syrian coast. The transfer of the locality belongs in the widespread significance of the god of Mount Kasios, Baal Saphon, later Zeus Kasios, to eastern Mediterranean seafarers. ${ }^{24}$ The place of religion and its topography in the formation of senses of maritime space needs separate consideration.

\section{Inviolatum sanctumque: Gods beyond the polis}

${ }^{23}$ Arnaud 2014. For the long-term history of the debatable maritime zone between Sicily and Africa, Bresc 2002.

${ }^{24}$ Bonnet 1987, 127. 
Gods and their rites were among the ways in which shape was given to the hard-to-imagine spaces of primarily maritime hegemony. The Rome-Carthage treaties were all, naturally, elaborately guaranteed by the deities of the communities involved. That can be seen from the fact that the Roman copies were preserved in the Area Capitolina, and Polybius was interested in explaining in some detail the sanctity of the Roman oath by Jupiter Lapis (3.25.6-9). Carthaginian deities are less fully evoked here, but given in full elsewhere (7.9.2-3). Sumbolaia brought about the conjunction of gods and observances, as is spectacularly demonstrated by the multi-lingual Pyrgi tablets, demonstrating Etruscan-Carthaginian interactions in the sanctuary of Caere's port. ${ }^{25}$

When Rome and Carthage looked at each other, one object of scrutiny, then, was certainly religious practices and customs. Cultic resemblances and differences, sanctuary allegiances and neutralities, were one of the languages in which the geography of power was expressed. The title of this section comes from Cicero's allusion to the sacred immunity from maritime hostilities of different kinds of the sanctuary of Tanit on Malta. ${ }^{26}$ The location of that sacred place closely resembled that of the Arae, where some sort of similarly ambiguous liminality was no doubt reinforced by the island's infernal origins and ephemeral nature. What remains of Quadrigarius'

\footnotetext{
${ }^{25}$ See now Bellelli and Xella 2016.
}

${ }^{26}$ Cic. Verr. 2.4.103, non modo illis Punicis bellis quae in his fere locis navali copia gesta atque versata sunt, sed etiam hac praedonum multitudine semper inviolatum sanctumque fuerit. Cf. also Lycophron, Alex., 1027-33 with Hornblower 2015 ad loc. 
notice certainly concerns the religious significance of the Arae, which probably had both maritime and underworld aspects. The name 'Neptuniae' at least confirms one Latin take on its cult. ${ }^{27}$ Which deities of the Carthaginian pantheon might have been venerated there? There is a prominent group of three sea-deities in the list of guarantors of Hannibal's treaty with Philip V in 215 BC, and Baal Saphon has been seen behind that list's Poseidon. ${ }^{28}$ As the god of Mount Kasios, victor in the battle with the monster Typhon, and protector and symbol of the links of Phoenician navigation all over the Mediterranean, he would be an intriguing presence on this ephemeral sanctuary-islet. ${ }^{29}$

There is nothing surprising about commemorating liminal locations and their significance to relations between polities with more or less permanent Altars. We have already seen the parallel between the Arae of the Graham Bank and the more famous Altars of the Philaeni between Cyrene and Carthage. ${ }^{30}$ Altars were well known as markers of furthest points, like Alexander's in the mountains of Central Asia, and this is not the only case of their situation on a

27 Strabo 6.2.11 (from Poseidonius): T. Flaminius (if that is the correct reading), governor of Sicily reported the sudden appearance of a later volcanic island in the Lipari group to the Senate, which ordered that it should be expiated with sacrifices specifically to both sea- and underworlddeities. Sisenna’s 'Propitious’ Altars is presumably an apotropaic or euphemistic usage.

${ }^{28}$ Barré 1983, 82-3.

${ }^{29}$ Tito 2012; Bonnet 1987.

${ }^{30}$ Quinn 2011 notes the parallel. 
small island to demarcate maritime space. Thus geographers record Arae dedicated by the Roman governor Sestius in the Atlantic on an island off Cape Finisterre. ${ }^{31}$

A further aspect of Polybius' scathing attack on Timaeus (12.24.4-5) was his preoccupation with religion. We should not share Polybius' hostility. Religious practices were by no means static and conservative characteristics of traditional polities. They were strongly relational, and expressed kinship, allegiance, superiority, victory and domination, as well as guaranteeing agreements and negotiations between polities of every size. The interest in the public role of religion exhibited in Quadrigarius' narrative might even be a hint that Timaeus was the Greek author on whom the Roman historians drew for these events.

The Sicilians caught in the middle between the territorial and functional self-definition of Carthaginians and Romans were in a position to observe these behaviours in a different light, from rather close up. In particular, one distinctive reciprocal religious modality of the western Mediterranean powers can be seen through Sicilian eyes, thanks to Cicero's Fourth Verrine oration. This was the transfer of cult, through the removal of cult-statues, as a sort of working spoil, with the related Roman practices which were by the late Republic codified as evocatio. ${ }^{32}$ This is of particular interest to the pursuit of regards croisés, because the practice lent itself to a

${ }^{31}$ Grüner 2005.

${ }^{32}$ For Assyrian precursors, Barré 1983, 44-5. It could later be believed that Rome’s sack of Volsinii in 264 had been motivated by the wish to remove 2,000 statues from the sanctuary, Pliny HN 34.34. 
kind of reprisal. The aggressive appropriation and counter-appropriation of religious materials formed a kind of exchange, and one in which imitation promoted convergence and symmetry. It was part of how the mirror worked.

Through Cicero (and with appropriate care), we can see that the removal of cult-statues was a prominent feature of the wars of Greeks and Carthaginians in Sicily. A case in point of the loss of cult-materials to Carthage is the narrative (Verr. 2.4.72-4) of how the image of Artemis from Segesta had retained cult, honour, and sanctity at Carthage, and been reinstated by Scipio Aemilianus from his spoils, to restored religious significance in its original home. The dedications of Mummius and Aemilianus in many towns of Italy made a statement in the same language even when restitution was not at issue.

Looking at the precedents for Augustus' removal of the ancient ivory image of Athena Alea from Tegea, as a punishment for the city's siding with Antony, Pausanias collected an interesting dossier, with mythological cases, famous instances from the Persian War, and restorations of the latter made by Seleucus I Nicator. ${ }^{33}$ The Romans believed they had practiced such behaviour from the early fourth century, when Juno had been elicited to Rome from Veii. The collection of cultic material was memorialised through the inventorising of re-dedicated materials, especially statues, and especially on the Capitol. Both habits may probably be predicated of the period when Rome was exploring new ways of documenting its achievements, and especially its developing set of dominant relationships with its neighbours, during the later

33 Pausanias 8.46.4, with 3.16.6: the Artemis Brauronia taken to Susa by the Persians presented to Laodicea at its foundation by Seleucus. 
fourth and third centuries. ${ }^{34}$ The Carthaginians had sent cult-statues captured in Sicily as much to their metropolis Tyre (the homeland of their ancestors', as Quintus Curtius puts it) as to Carthage itself, and one of Apollo from Gela was especially sacred. During Alexander’s siege, the Tyrians became uncertain of its allegiance, and bound it to the altars of Herakles to prevent the god's deserting them - unsuccessfully. ${ }^{35}$ We happen to know that the strange story of this colossal statue was described by Timaeus. Hamilcar, after sacking Akragas in 406 BC, had removed this celebrated image from a suburb of Gela. ${ }^{36}$ Timaeus claimed that the precise moment of the theft had been recorded (a claim about time-measurement not without its problems) and that Alexander's capture of Tyre avenged the sacrilege at exactly that moment in $332 \mathrm{BC}$. The chronological marvel is very Timaean, but so is the interest in how the fortunes of the sacred, and the interplay of allegiance and justice, patterned the relationships of whole communities across a wide sweep of history. ${ }^{37}$

${ }^{34}$ On the memorial culture which preceded and fed into the first Roman historiography, Purcell 2004.

${ }^{35}$ Curtius Rufus 4.3.9 Syracusis id simulacrum devexerant Poeni et in maiorum locaverant patria multisque aliis spoliis urbium a semet captarum non Carthaginem magis quam Tyrum ornaverant.

${ }^{36}$ Carthaginian theft of Apollo of Gela, 404 BC, Diodorus 13.16 (Timaeus F 106).

${ }^{37}$ Timaeus was also, of course, inserting Alexander's victories into the scheme of enemies of Greece in East and West which Herodotus had employed: Feeney 2007, 47-52. 
The story also shows the concern of the historian and his audiences for the order of religiosity, and the difficult and dangerous place of the gods in the fabric of human states. Ancient reflection on replications of cult is also to be seen in the scattered evidence concerning aphidrumata, the peaceful and consenting transfer of religious practice, the acceptable equivalent of the violent dislocations. On this view Rome and Massalia could be seen as linked to Phocaea and Ephesos in a manner parallel to Carthage's cultic ties to Tyre. Although the first description of an aphidruma is Herodotus', it is not the claim of distant origins which interests me here, but the perception of the pattern and the dissemination of this kind of explanation and its consequences. $^{38}$

It is clear that Timaeus took at least some interest in Roman religion too, and how it might have been related to that of other peoples. ${ }^{39}$ That is a particular instance of a more general concern, in his investigation of the worlds in the west, for the counter-pointings made by the removals and relocations of religious spoils. ${ }^{40}$ The cultic geography of Sicilians was complex, and transcended the frame of the polis. That complexity was reflected also in their dealings with

38 See recently Bonnet 2014, for subtle reflections on Phoenician and Greek mutual interpretations.

39 Timaeus (F 36 Jacoby) on the equus October, cited in support of Rome's Trojan origin, Polybius 12.4.b 1.

${ }^{40}$ Timaeus' concern with Italy, Sicily, Africa, Polybius 39, 8, 5. For religion and exchange, recently Demetriou 2012 Negotiating identity. 
and imaginings of the great powers to north and south, and the ways in which those cultural systems perceived each other.

\section{5. 'Competitive and incompatible worlds'}

Gods were hard to confine politically, even by the golden chains of the Tyrians in 332. In a sense, they stood for all the resources and advantages for which communities competed. The pursuit of survival and prosperity entailed a larger-than-polis vision; looking beyond the territories of individual poleis meant that ancient historians, from Thucydides on, could not neglect economic themes. In the mobilisation of people and materials, in production, redistribution, and exchange, and in fiscal resources, then, lay another area central to the mutual cross-evaluation and comparative assessment of polities. Polybius' treaty-dossier, once again, demonstrates the communities' own awarenesses of the ingredients of such an analysis. Here is a dialectical account of everyday behaviour, revealing the ideas which shaped large-scale Mediterranean hegemonies. And it is into this context of the formation of larger collectivities and the harnessing of resources across them that we should fit the evidence, literary or archaeological, for the vigour of maritime exchange in the western Mediterranean in the late Classical age ${ }^{41} \mathrm{~A}$ key point is the claim that Romans were excluded from the emporia of Carthage, because of the excellence of the

\footnotetext{
${ }^{41}$ Becthold 2007 'Alcune osservazioni sui rapporti commerciali’
} 
territory. ${ }^{42}$ It was essential to control information about productivity and the centres through which what is produced was mobilised and redistributed. Historians, equally, were interested in the perceptions of demographic, economic, and fiscal systems as they affected decisions about peace and war. ${ }^{43}$ Hence the very well-known descriptions in Polybius and Diodorus of the intensive agriculture of the immediate environs of Carthage; we may compare Pyrrhus' rueful remarks about the investment agriculture of the territories controlled by his Roman opponents. ${ }^{44}$

Such evaluations of resources could not be made without thinking about maritime spatialities. A neglected passage of Polybius (10.1), for instance, explaining why the Romans were concerned with Taras during the Second Punic War, evokes in some detail what we should call its hinterland or catchment area - not a territory in the normal sense, but an extended maritime space reaching from Sicily to Greece and right up the Adriatic. Sailors from east and west were compelled to go to Taras to conduct their exchanges (ameipseis) and 'oikonomiai' with the peoples of this side of Italy. This use of oikonomia to mean a particular pattern, rhythm,

${ }^{42}$ Polybius, 3, 23, 2, cf. 31, 21, Massinissa and the Emporia. Bresson 2006 on this theme. Palmer 1997, 19-21 connects the role of the aediles in preserving the treaties with their responsibility for supervising markets.

43 This too is likely to have been prominent in Timaeus, who is often seen behind the notably economic section on the Isles of the West at Diodorus 5, 1-24. Note also Timaeus F 49 on Sybarite truphe, with Dench 2005 Romulus’ Asylum, 284-5.

${ }^{44}$ Polybius 1, 29, 7 the villas of Carthage and 20,000 slaves; Diodorus, 20, 8. Pyrrhus: Dio 9, 27. 
configuration, of economic behaviour developed for a specific community is hard to parallel (and apparently unfamiliar to modern historians).

Seen from the polis, the organisational and social texture of larger hegemonies was bewildering and chaotic. Plato (Laws 693) thought that Persian rule resulted in an inextricable confusion of ethnicities. In the Carthaginian and Roman dominions too, ethnicity was a far more complex matter than could have fitted with the political theories of the polis. The larger structures of political authority, the foundation of subsidiary settlements, the management of demographic resources, and especially structures of recruitment, the integration of regions through enhanced communications by sea and land, took their very varied place alongside religious allegiance and economic mobilisation to give each hegemony its own character in each period. ${ }^{45}$ In all this, nucleated settlements played much more varied roles than is familiar from the polis-universe. The founding of subsidiary cities to articulate regional power is a concern of the Polybian treaty-dossier (thus in the treaty of 348, Polybius 3.24.4). Thucydides already (6.2.6) saw Carthaginian settlement in Sicily as a matter of strategic planning of the interdependence of sea and land. Populousness, and the results of demographic policy, attracted observers' notice from Philip V's letter to Larisa to Polybius' notice of the size and relative youth of the Carthaginian demos.

The regards croisés of Carthaginians and Romans changed both. But they had a larger effect too. Intersecting with the usually suspicious mutual inspections of Carthaginians and

\footnotetext{
${ }^{45}$ Polybius 3, 10, 5 Hamilcar's foundations in Spain; 3, 22, 13 sixth-century Carthaginians not to build forts in Latium. On mercenaries, Fariselli 2002; Péré-Nogués 2011; Cherici 2007.
} 
Romans, there was an even larger binary, between the polis and the collectivity of poleis on the one hand, and on the other, the larger, city-state-transcending, hegemony. The play of interlocking analyses can be traced across that major divide too. Since the core of both the Carthaginian and Roman polities was a single urban centre, this larger disjunction also came to matter to each of the two states' evaluation of itself and the other. The two polities could, and can, be perceived as similar kinds of alternatives to the polis. Just as poleis reflected on each other and reflected each other, coming to understand that being a polis was being part of a sequence, a series, a set with many, or many hundred, members, sharing certain characteristics, so these two different communities looked at each other, and for all the suspicion and jealousy in that gaze, came to constitute a pair, changing ever so subtly through their shared consciousness of being different in kind from their Hellenic neighbours in west, and still more, east.

If the comparison of pairs of adversaries is as old as literature, the contrast of poliadic and other political systems is coeval with ancient historiography, and Carthage was involved from the start, from Herodotus' complex oppositions of Greeks with non-Greek foes to east and west, summed up in the notorious Himera-Salamis synchronism. ${ }^{46}$ Thucydides' extended analysis of the differences between Lacedaimonian and Athenian polities and alliance-systems took the genre further. In both these celebrated and influential cases, what we call the polis is thoroughly problematised. Persia and Carthage are both alternatives to the Greek community in their nomoi; between Sparta and Athens - and Sicily - it is not the pre-eminence of a unified model of the poliadic state, but the absence of a single, stable, structure of either community organisation or

\footnotetext{
${ }^{46}$ Herodotus 7.166; Asheri 1991-2.
} 
social form, which emerges most clearly. Alternatives to the polis are constantly on show, and they too can be studied comparatively, as parallels, mirror-images, binary pairs.

Rome and Carthage adapted to this hermeneutic. They were presented, and came to see themselves, as alternatives to the Greek city. Here is our way out of the old problem of how to cram these sprawling and changeable polities into poliadic pigeon-holes. If Rome and Carthage weren't, or weren't exactly, poleis, what shall we say about them instead? And might it be helpful to say the same kind of thing about both?

In a stimulating recent article on Polybius' economic representations, John Davies reflects robustly on the plurality of systems in the mid-Hellenistic oikoumene, using the phrase which forms the heading of this section. ${ }^{47}$ Again, he speaks of 'conflicts between three opposed forms of collective behaviour'. The two greater hegemonies of the West in the early Hellenistic period, locked in mutual regard, rivalry and imitation, were themselves a 'competitive or incompatible world', pitted, by Aristotle for instance, against the more familiar world of poleis. That same stand-off was one of the themes of Momigliano's classic article on Timaeus of seventy years ago, which identified a gran rifiuto to engage with the royal histories which were the inevitable consequence of the establishment of the Diadochs. Timaeus on this view can be characterised above all by a silence, by a turning away - from all that was happening in the Aegean and points East. ${ }^{48}$ He was concerned with alternatives to the imperial systems of the Diadochs as much as to

${ }^{47}$ Davies 2013, 335.

${ }^{48}$ Momigliano 1959; Pearson 1987; Baron 2013. 
traditional polis-power. Hence his choice of Pyrrhus as the peg on which to hang an exposition of Rome and its history. Rome’s victory was not just over Greeks, but over an Alexander-style King (indeed one related to Alexander). The foolishness of the landsman Pyrrhus attacking the TyrianCarthaginian seapower as it besieged Syracuse (Pausanias 1.12.5)—here is precisely the kind of theme which made Pyrrhus interesting to Timaeus. Momigliano also emphasized the importance of the symmetry between Carthage and Rome, and his preference for the view (he felt unable to assert it definitely) that this was already a feature of Timaeus' Sicilian History, and not only of the Pyrrhus monograph.

Despite his virulence against his predecessor, Polybius’ own refusal, in his famous choice of a practical history of actions, as against polis history, with its accounts of foundations and kinship between cities, is cognate, and the two should be compared. Polybius, importantly, divided his subject-matter by theme rather than types of community or geographical location. But his strategy, like Aristotle's and Timaeus', served to encapsulate and delimit a zone of traditional polis consciousnesses, beyond which these authors looked into new social orders and configurations, with considerable curiosity and originality. At the same time, the 'Hellas of poleis', the 'joined-up Hellas' of Pseudo-Skylax, developed ever more clearly a consistency based on the perceived replicability and core-institutions of the city-state community, clearly demarcated from the alternatives to west and east. Meanwhile, we should not overlook the extent to which the crossing perceptions of Carthage and Rome gave both a sense of powerful identity precisely in contra-distinction to the Greek milieux of poleis wherever they were to be found. ${ }^{49}$

${ }^{49}$ Dench 1995, 68-9. 


\section{6. 'Power beyond what is acceptable' - a pivotal age}

In the famous speech which Polybius gives to Agelaus of Naupactus evoking 'the clouds in the West' - the change in the weather soon to affect all the Hellenic world - the threat of Rome is described as that of transgressive, excessive, unreasonably large, power, dunamis pera tou deontos (Polybius 5.104.3).

The problem of dominion on a scale too great for easy intuition had been familiar since Greeks met Neo-Assyrians, Neo-Babylonians, and Persians. The destruction and reworking of the far-flung authority of the last, in the last quarter of the fourth century, entailed new thinking about all the conceptual issues of empire, thinking which may be glimpsed in the revolution in the management of time manifested in the Seleucid era, as in the new habits of organising distance and area, a widespread cognitive shift in which what we know as Hellenistic geography is only the theoretically complex superstructure. Much wider processus de territorialisation et de spatialisation were involved too. ${ }^{50}$ The treaty of the Arae Neptuniae shows us such changes at work in the west as well as the east, in maritime as much as in continental contexts.

In the last decades of the fourth century, both Carthaginian and Roman polities applied old techniques on ever wider scales and in more and more intricate patterns, as they expanded their increasingly imperial reach. Roman settlement, reaching further afield since 338, and

\footnotetext{
${ }^{50}$ Capdetrey 2015, reviewing Kosmin 2014, which addresses precisely these themes.
} 
equipped, it seems, with the latest in Greek agrimensorial techniques, pulled together the territories of the scattered new rural tribus far to the south with the grand gesture of the Via Appia. ${ }^{51}$ Appius' road also enacted a symbolic between Rome and the greatest of its allies. The message was received in the same generation by M' Curius Dentatus, whose subjugation of Sabinum followed the symbolic precedents of Appius - new tribus, new aqueducts bringing Sabine water to Rome, new roads binding Sabinum to Roman communications, new institutions to benefit the fiscality of the Roman People, these were the marks of a pattern in conquest and lasting dependence, if not assimilation. At sea, too, Rome now faced the challenge of the control of the harbour of Antium, and was developing the Tiber mouth, as well as sequences of fortified posts along the Tyrrhenian coasts. This was the age when Roman pistis became a rallying point, and when a new sense of Italia was shaped, largely in Rome's interest. ${ }^{52}$ The Treaty of Philinus and the notice of Quadrigarius, which might be questioned on a 'small Rome' hypothesis, in fact fit well with this period of innovation and spatial ambition.

As for Carthage, this was the age of the consolidation of a Carthaginian epikrateia in Sardinia, Sicily and Spain. ${ }^{53}$ In the same year as the treaty recorded by Quadrigarius, Carthage

${ }^{51}$ Purcell 2012 for the geographical consciousness in Roman actions of this period. Humm 1996 and 2005. For changes in consciousness of time at Rome in this age, Purcell 2003; also Catalano 1978.

${ }^{52}$ Raaflaub 1992; Lepore 1963, 99. Dench 1995, 71; Russo 2012.

${ }^{53}$ Bibliography includes Acquaro 1978; Manfredi 2003; Ameling 2011. 
made a treaty with Syracuse by which the latter received 200,000 medimnoi of grain and at least 150 talents in gold. This was a mobilising and disposing power which might well be thought 'beyond what was reasonable' (Diodorus 20.79.5; Justin 22.8.15). In the waters which particularly concern us in this argument, the island of the Graham Bank is a seamark answering to a crucial boundary-zone on the south coast of Sicily, the Halykos line, which separated Carthaginian and Syracusan spheres in the treaty of 338; that of 313 gave Herakleia to Carthage, but the zone remained transitional. Romans were not yet much involved in the terrestrial politics of Sicily; but they - the 'Itali' who named the Arae - were all over the seaways of the Mediterranean. The vanishing island meant something in relation to Carthage's territorial selfdefinition in Sicilian space, but it also served at the same time as a point of reference in those much harder to intuit spheres of movement, zones of exclusion, and overlapping rights and obligations which expressed hegemony across the seas.

Such a choice for a negotiation between these powers, reflecting, as I have argued, their parallel development and mutual scrutiny, would have been an appropriate subject for Timaeus of Tauromenium. Indeed, if the treaty received detailed presentation by Timaeus as well as Philinus, we have another reason for Polybius' scepticism and silence. There can be no certainty, and there were no doubt many moments of negotiation which have vanished entirely from the record. What matters is rather that at some point in the generations immediately preceding the First Punic War, Carthage and Rome engaged in one particular reciprocal exchange which, whenever precisely we should situate it, speaks eloquently of the conceptual horizons of two states engaged in the crossed perceptions of a decades-old game of mirrors.

There might be several sequels to the argument which I have developed here. The first 
would explore how the mutually mirrored self-imaginings of Carthage and Rome shaped and were developed by the First Punic War. ${ }^{54}$ That enquiry has wider implications than direct imitation or differentiation of one power from another: the habit of comparison and considered self-positioning must be relevant to the thought-world of Livius Andronicus and his reception at Rome. After 241, both hegemonies clearly moved towards more closely integrated and effective systems of mobilisation and management of resources. ${ }^{55} \mathrm{I}$ am even more interested in how this long process of comparison can help us understand the habits of mind revealed fully developed in the diplomatic practice of the age of the Second Punic War and the first quarter of the second century.$^{56}$ The interest of Fabius Pictor and his generation in inserting Rome into a Thucydidean agon of imperial polities might have antecedents outside the reception of Greek historiography at Rome. The analysis of the regards croisés, finally, could be explored in the horizons of Lycophron and Ennius, while the long history of the comparison of Rome and Carthage which I have sketched so briefly here is an important factor in the elaboration of the parallelisms of city with city and culture with culture which were so elaborately drawn by Roman attitudes and actions in the Third Punic War. ${ }^{57}$ The structural oppositions which Timaeus saw, and helped to

${ }^{54}$ See recently Hoyos 2015.

${ }^{55}$ Hoyos 2011.

${ }^{56}$ Polybius 10.40.7, for instance, describes Africanus' sway "from the Altars of the Philaeni to the Pillars of Herakles”.

${ }^{57}$ Berti 1990 for one act of this period which fits particularly well into the picture drawn here. 
shape, issued and ended in $146 .^{58}$

${ }^{58}$ Purcell 1994 explores a world created out of these habits of thought and behaviour. 


\section{Bibliography}

Acquaro, E. 1978. Cartagine: un impero sul Mediterraneo. Rome.

Ameling, W. 2011. The rise of Carthage to 254. In Hoyos 2011, 39-57.

Arnaud, P. 2014. Ancient mariners between experience and common sense geography. In Features of common sense geography: implicit knowledge structures in geographic texts, ed. K. Geus and M. Thiering, 39-68. Zürich.

Asheri, D. 1991-2. The art of synchronization in Greek history: the case of Timaeus of Tauromenium. SCI 11: 52-89.

Baron, C.A. 2013. Timaeus of Tauromenium and Hellenistic historiography. Cambridge.

Barré, M.L. 1983. The god-list in the treaty between Hannibal and Philip V of Macedonia, Baltimore.

Becthold, B. 2007. Alcune osservazione sui rapporti commerciali fra Cartagine, la Sicilia occidentale e la Campania (IV-metà del II sec. a.C.): nuovi dati basati sulla distribuzione di ceramiche campane e nordafricane/cartaginesi', BABesch 82.1: 51-76. 
Bellelli, V., and Xella, P., eds. 2016. Le lamine di Pyrgi: nuovi studi sulle iscrizioni in etrusco e in fenicio nel cinquantenario della scoperta. Verona.

Berti, N. 1990. Scipione Emiliano, Caio Gracco e l’evocatio di “Giunone” da Cartagine. Aevum 64: 69-75.

Bonnet, C. 2015. Les enfants de Cadmos: le paysage religieux de la Phénicie hellénistique. Paris.

Bonnet, C. 1987. Typhon et Baal Saphon. Studia Phoenicia 5: 101-43.

Bresc, H. 2002. Du ribât au presidio, les enjeux et les contrôles des Détroits siciliens. In Controllo degli Stretti e insediamenti militari nel Mediterraneano. Coll. Spoleto 1997, 97-127.

Rome.

Bresson, A. 2005. Les accords romano-carthaginois. In La mobilité des personnes en Méditerranée, de l'Antiquité à l'époque moderne. Procédures de contrôle et documents d'identification, ed. C. Moatti, 649-76. Rome.

Briscoe, J. 2013a. Q. Claudius Quadrigarius. In Cornell 2013, vol. III, 300-29.

Briscoe, J. 2013.b L. Cornelius Sisenna. In Cornell 2013, vol. III, 368-417. 
Camous, T. 2007. Les phéniciens dans l'historiographie romaine et la sous-évaluation du rôle joué par les influences phéniciennes dans la république avant les Guerres Puniques. REA 109: $227-46$.

Capdetrey, L. 2015 Review of Kosmin 2014, BMCR.

Cary, M. 1919. A forgotten treaty. JRS 9: 67-77.

Catalano, P. 1978. Aspetti spaziali del sistema giuridico-religioso romano: mundus, templum, urbs, ager, Latium, Italia. ANRW II 16, 1, 525-53.

Cornell, T., et al., eds. 2013. The fragments of the Roman historians. Oxford.

Davies, J.K. 2013. Mediterranean economies through the text of Polybius. In Gibson and Harrison, eds. 2013, 319-35.

Demetriou, D. 2012. Negotiating identity in the ancient Mediterranean: the archaic and classical Greek multiethnic emporia. Cambridge.

Dench, E. 1995. From barbarians to New Men. Oxford.

Dench, E. 2005. Romulus’ Asylum. Oxford. 
Fariselli, A.C. 2002. I mercenari di Cartagine. La Spezia.

Feeney, D. 2007. Caesar's Calendar: ancient time and the beginnings of history. Berkeley.

Gibson, B., and Harrison, T., eds. 2013. Polybius and his world: essays in memory of F.W. Walbank. Oxford.

Grüner, A. 2005. Die Altäre des L. Sestius Quirinalis bei Kap Finisterre. Zur geopolitischen Konstruktion des römischen Herrschaftsraums. Madrider Mitteilungen 46: 247-266.

Heurgon, J. 1969. Rome et la méditerranée occidentale jusqu'aux guerres puniques. Paris.

Hornblower, S. 2015. Lykophron: Alexandra: Greek text, translation, commentary and introduction. Oxford.

Hoyos, D. 2011b. Carthage in Africa and Spain, 241-218 BC. In Hoyos, ed. 2011a, 204-22.

Hoyos, D., ed. 2011a. A companion to the Punic Wars. Oxford.

Hoyos, D. 2015. Mastering the West: Rome and Carthage at War. Oxford. 
Humm, M. 1996. Appius Claudius Caecus et la construction de la Via Appia, MEFRA 108: 693746.

Humm, M. 2005. Appius Claudius Caecus. La République accomplie. Rome.

Kolendo, J. 1971. L'influence de Carthage sur la civilisation matérielle de Rome. Archeologia [Warsaw] 22: 9-22.

Kosmin, P.J. 2014. The land of the elephant kings: space, territory, and ideology in the Seleucid Empire. Cambridge, MA.

Ladewig, M. 2014. Rom - Die antike Seerepublik: Untersuchungen zur Thalassokratie der res publica populi romani von den Anfängen bis zur Begründung des Principat. Stuttgart.

Langewiesche, W. 2004. Outlaw sea: a world of freedom, chaos and crime. London.

Lepore, E. 1963. L’ITA IIA nella formazione della communità romano-italica. Klearchos 5: 89113.

Manfredi, L.-I. 2003. La politica amministrativa di Cartagine in Africa. Rome.

Marcotte, D. 1988. Origines puniques de la topographie romaine. Studia Phoenicia.6: 73-83. 
Momigliano, A. 1959. Athens in the third century B.C. and the discovery of Rome in the Histories of Timaeus of Tauromenium. In Essays in ancient and modern historiography, 1977, 37-66. Oxford

Moret, P. 1997. Planesiae: îles erratiques de l'occident grec. REG 110: 25-56.

Moret, P. 2002. Mastia tarseion y el problema geografico del segundo tratado entre Cartago y Roma. Mainake 24: 257-76.

Oakley, S.P. 1998. A Commentary on Livy, Books VI-X. Volume II: Books VII-VIII. Oxford.

Palmer, R.E.A. 1997. Rome and Carthage at peace. Stuttgart.

Pearson, L. 1987. The Greek historians of the west: Timaeus and his predecessors. Atlanta.

Péré-Nogués, S. 2011. Aux limites de l’interprétation: mercenariat et mobilité au second âge de fer. In L'âge du Fer en Aquitaine et sur ses marges. Mobilité des hommes, diffusion des idées, circulation des biens dans l'espace européen à l'âge du Fer: Actes du 35e colloque international de l'Association Française pour l'Etude de l'Âge du Fer, ed. A. Colin and F. Verdin, 429-37. Bordeaux. 
Purcell, N. 1995. On the sacking of Carthage and Corinth. In Ethics and Rhetoric. Classical Studies for Donald Russell on his Seventy-Fifth birthday, ed. D. Innes, H. Hine and C. Pelling, 133-48. Oxford.

Purcell, N. 2003. Becoming historical: the Roman case. In Myth, History and Culture in Republican Rome: studies in honour of T.P. Wiseman, ed. D. Braund and C. Gill, 12-40. Exeter.

Purcell, N. 2012. Rivers and the geography of power. Pallas 90: 373-87.

Quinn, J.C. 2011. The Syrtes between East and West. In Money, trade and trade routes in preIslamic Africa, ed. A. Dowler and L. Galvin, 11-20. London.

Quinn, J.C. 2013. Imagining the imperial Mediterranean. In Gibson and Harrison 2013, 337-52.

Quinn, J.C. 2014. A Carthaginian perspective on the Altars of the Philaeni. In Quinn and Vella 2014, 169-79.

Quinn, J.C., and Vella, N.C., eds. 2014. The Punic Mediterranean: identities and identification from Phoenician settlement to Roman rule. Cambridge.

Raaflaub, K. 1992. Rome, Italy and Ap. Claudius Caecus before the Pyrrhic War. In The Age of Pyrrhus: papers delivered at the International Conference, Brown University, 8-10 April, 1988, 
ed. T. Hackens,13-50. Providence, RI.

Russo, F. 2012. The beginning of the First Punic War and the concept of Italia. In Integration and Identity in the Roman Republic, Proceedings of the International Conference, Manchester 2010, ed. S. Roselaar, 17-34. Leiden.

Scardigli, B. 1991. I trattati romano-cartaginesi. Pisa.

Scardigli, B. 2011. Early Relations between Rome and Carthage. In Hoyos, ed. 2011, 28-38.

Sharp, N. 2005. Saltwater people: the waves of memory. Crows Nest, NSW.

Tito, V. 2012. Zeus Kasios. Un culto montano a tutela della navigazione. In Tradizione, tecnologia e territorio, ed. E. Tortorici, 81-106. Rome.

Vattuone, R. 1991. Sapienza d'Occidente: il pensiero storico di Timeo di Tauromenio. Bologna.

Vollmer, A. 1877. Die römisch-karthagischen Verträge. RhM 32: 614-626. 